\title{
Vine prunings biomass as fuel in wood stoves for thermal power production
}

\author{
Marco Puglia, Simone Pedrazzi ${ }^{*}$, Giulio Allesina, Nicolò Morselli, Paolo Tartarini \\ BEELab (Bioenergy efficiency laboratory), Dept. of Engineering "Enzo Ferrari”, Via Vivarelli \\ 10/1, Modena 41125, Italy
}

Email: simone.pedrazzi@unimore.it

\begin{abstract}
Wine industries by-products consist in various biomasses. The major in abundance are the vine prunings, derived from the annual vine plant maintenance. Literature suggests a variable production of 1-5 ton/year for every hectare of vine plantation. Vine prunings have a higher heating value of about $18 \mathrm{MJ} / \mathrm{kg}$ and an ash amount of about $4 \%$. This paper analyzes the behavior as solid fuel in domestic stove of 4 variety of vine prunings from Emilia Romagna, a region in the north of Italy. First, physical and chemical characterization of the biomass samples were performed, then ash sintering and melting temperatures were evaluated. Combustion tests on a commercial multi-fuel biomass stove were performed. During the tests, mean combustion temperatures, biomass consumption, thermal power and combustion efficiency were calculated and compared with data regarding tests with A1 plus wood pellets. In addition, qualitative results about biomass sintering and stove flame stability was discussed. Results show a thermal efficiency comparable to the one obtained with wood pellet and the sintering of ashes was neglectable. Concluding, pre-treated vine prunings confirmed good properties as fuel in wood stove.
\end{abstract}

Keywords: Efficiency, Power, Prunings, Stove, Vine.

\section{INTRODUCTION}

In Italy, about 800 thousand hectares are dedicated to vine cultivation (Agri ISTAT estimates) [1], that represent $20 \%$ of the entire European wine production [2].

The amount of vine prunings produced in an hectar over a year depends on the type of vine, age, way of harvesting, configuration of terrain etc. [3]. Generally, it varies between 1 and $5 \mathrm{t} /$ ha $[4,5]$.

This kind of byproducts are often directly burned in the field, used as organic fertilizer or disposed of [3]. Open - air burning release a variety of pollutants [6], especially heavy particulate [7], hence utilizing vine prunings as a fuel in commercial boilers or furnaces can be a convenient alternative with a lower environmental impact compared to the status quo [6].

Using chopped residues as fertilizer can be useful in presence of healthy vineyard, otherwise prunings can be a dangerous infection source for grape diseases as esca or root $\operatorname{rot}[1]$.

First, four varieties of vine prunings were collected, in particular they were Trebbiano, Salamino, Sangiovese, Grasparossa. This biomass was characterized through physical and chemical analysis to evaluate the possibility of using it as fuel. In particular, elemental analysis was performed to measure the quantitative of four elements $(\mathrm{C}, \mathrm{H}, \mathrm{N}$ and $\mathrm{S})$ in the various kinds of prunings, and then the ash sintering and melting temperatures were obtained. After these preliminary evaluations, the biomass was processed to be suitable for its combustion in a commercial multi-fuel stove. Measuring some significant parameters of the test was possible to calculate the power output and the consumption of the stove, and therefore even its efficiency. These results were compared with the ones obtained with A1 plus wood pellets.

Lastly, the brazier was examined to eventually detect the presence of ash agglomerates after the tests.

\section{MATHERIAL AND METHODS}

\subsection{General procedure}

The chemical and physical analysis carried out on the biomass were the ultimate analyses, the ash quantity determination and the ash sintering, softening and melting temperatures. With a CHNS - O analyzer was possible to obtain the percentage of carbon, hydrogen, nitrogen and sulfur contained in the samples, after a preliminary drying to determine the moisture content. The ash amount was measured through a 4 hours muffle furnace calcination [8]. Ash sintering, softening and melting temperatures were detected with a thermogravimetric analyses.

To perform the combustion test, a processing of the prunings was necessary to reduce their length. For this purpose a rotary valve was used. Exploiting the blade of the valve, 
through a series of subsequent steps was possible to reduce the length from about $1 \mathrm{~m}$ to few centimeters.
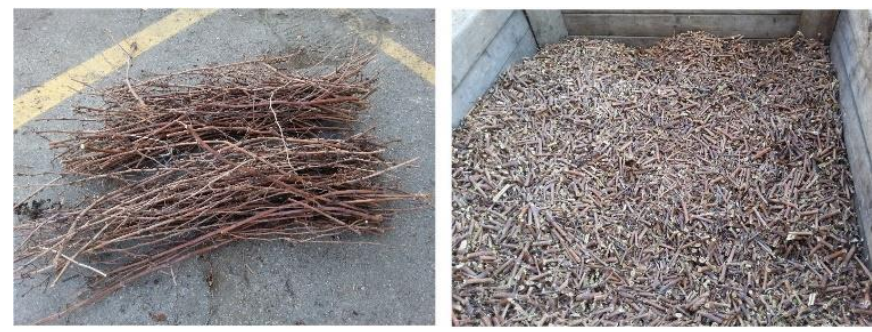

Figure 1. Prunings before (left) and after (right) the processing

Once the size of the fuel was suitable for the feeding of the hot air generator the test was ready to start. A $29 \mathrm{~kW}_{\text {th }}$ Ecofaber GA Ghibli was used for the combustion and the hot air generation. The exhausts passing in a heat exchanger increased the temperature of the air flow. The anemometer Extech HD 300 was used to measure the velocity of hot air flow. The biomass consumption was monitored weighing the fuel used to feed the hot air generator.

With four thermocouples connected to a TC-08 Data Logger the temperatures of fumes, ambient, combustion chamber and hot air were monitored.

The data collection system for the efficiency calculation is summarized in Figure 2.

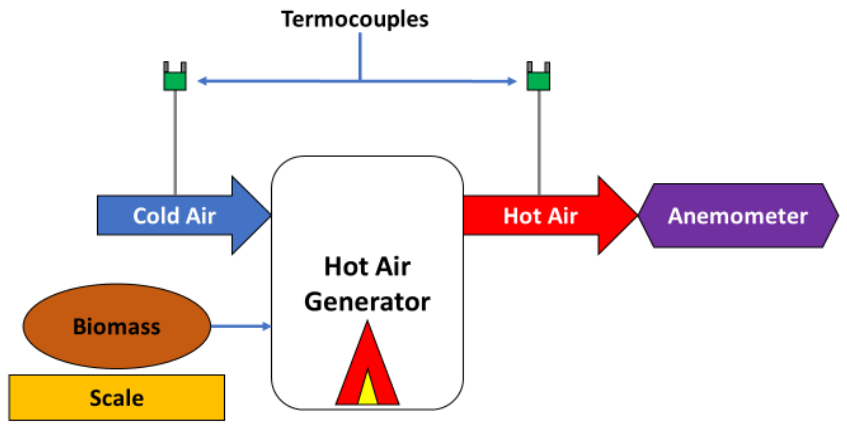

Figure 2. Data collection system

\subsection{Equations}

Biomass moisture is expressed on wet basis and calculated with $\mathrm{Eq}(1)$ [9]:

$M o_{w e t}=\frac{W_{w e t}-W_{d r y}}{W_{w e t}}$

The biomass higher heating value was calculated with the Channiwala and Parikh correlation Eq(2) [9] utilizing the results from the ultimate analyses and the ash determination:

$H H V=349.1 C+1178.3 H+100.5 S-103.4 O-15.1 N-$ $21.1 \mathrm{ASH} \mathrm{kJ} / \mathrm{kg}$

To measure the hot volumetric air flow $\operatorname{Eq(3)}$ was used:

$Q=S e \cdot v$ where $\mathrm{Q}$ is the hot air volumetric flow, Se is the sectional area of the tube $\left(0.0295 \mathrm{~m}^{2}\right)$ and $\mathrm{v}$ is the air flow velocity measured with the anemometer.

Knowing the hot air volumetric flow and the difference between the temperature between the ambient and the hot air, it is possible to calculate the Thermal Power Output with Eq(5).

$P=Q \cdot \Delta T \cdot c_{p, \text { air }} \cdot \rho_{\text {air }}$

The efficiency of the hot air generator can be calculated with $\mathrm{Eq}(6)$.

$\eta=P /\left(M_{d r y} \cdot H H V\right)$

$\mathrm{M}_{\text {dry }}$ is the dry biomass consumption calculated as:

$M_{d r y}=\frac{M_{w e t}\left(100-M o_{w e t}\right)}{100}$

\section{RESULTS.}

\subsection{Biomass analysis}

In Table 1 the percentages of Carbon, Hydrogen, Nitrogen and Sulfur in the biomass are shown.

Table 1. Biomass ultimate analysis

\begin{tabular}{ccccc}
\hline Biomass & $\mathrm{C}[\%]$ & $\mathrm{H}[\%]$ & $\mathrm{N} \mathrm{[ \% ]}$ & $\mathrm{S}[\%]$ \\
\hline San & 44.46 & 6.49 & 0.84 & 0.00 \\
& \pm 0.01 & \pm 0.01 & \pm 0.01 & \pm 0.01 \\
\hline Sal & 43.78 & 6.47 & 0.43 & 0.00 \\
& \pm 0.01 & \pm 0.01 & \pm 0.01 & \pm 0.01 \\
\hline Treb & 44.71 & 6.57 & 0.11 & 0.00 \\
& \pm 0.01 & \pm 0.01 & \pm 0.01 & \pm 0.01 \\
\hline Gras & 46.00 & 6.61 & 0.30 & 0.00 \\
& \pm 0.01 & \pm 0.01 & \pm 0.01 & \pm 0.01 \\
\hline
\end{tabular}

In Table 2 the ash amount obtained with 4 hours muffle furnace calcination at $550{ }^{\circ} \mathrm{C}$ is indicated.

Table 2. Ash amount in the biomass

\begin{tabular}{ccc}
\hline Biomass & Weight loss [\%] & Ash amount [\%] \\
\hline Sangiovese & $95.5 \pm 0.1$ & $4.5 \pm 0.1$ \\
\hline Salamino & $96.5 \pm 0.1$ & $3.5 \pm 0.1$ \\
\hline Trebbiano & $96.6 \pm 0.1$ & $3.4 \pm 0.1$ \\
\hline Grasparossa & $97.1 \pm 0.1$ & $2.9 \pm 0.1$ \\
\hline
\end{tabular}

In Table 3 there are ash sintering, softening and melting temperatures detected with the thermogravimetric analyses reported in Figures 3,4,5,6.

Table 3. Ash sintering, softening and melting temperatures

\begin{tabular}{cccc}
\hline Biomass & Sintering T & Softening T & Melting T \\
\hline Sangiovese & $1237{ }^{\circ} \mathrm{C}$ & $1330{ }^{\circ} \mathrm{C}$ & $1538^{\circ} \mathrm{C}$ \\
\hline Salamino & $1045^{\circ} \mathrm{C}$ & $1348{ }^{\circ} \mathrm{C}$ & $1465{ }^{\circ} \mathrm{C}$ \\
\hline Trebbiano & $1143{ }^{\circ} \mathrm{C}$ & $1344{ }^{\circ} \mathrm{C}$ & $1495^{\circ} \mathrm{C}$ \\
\hline Grasparossa & $1242{ }^{\circ} \mathrm{C}$ & $1355^{\circ} \mathrm{C}$ & $1477{ }^{\circ} \mathrm{C}$
\end{tabular}




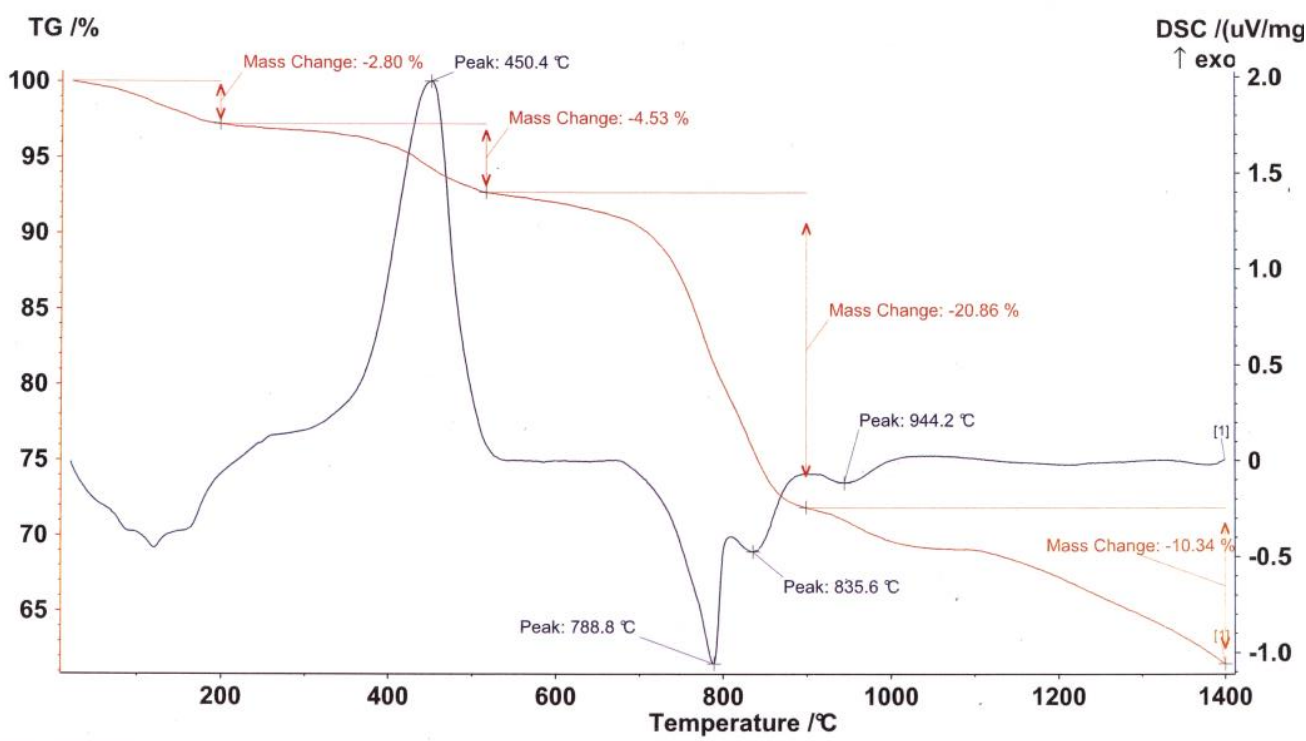

Figure 3. Sangiovese thermogravimetric analyses

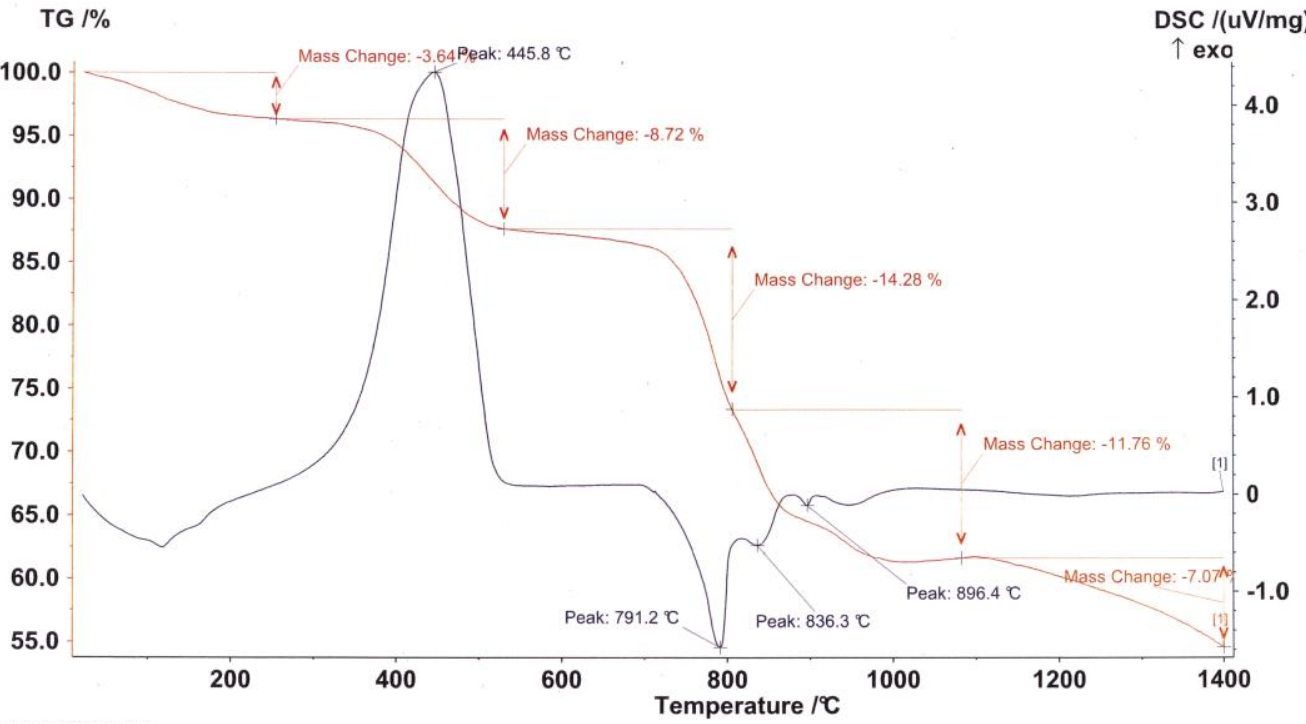

Figure 4. Trebbiano thermogravimetric analyses

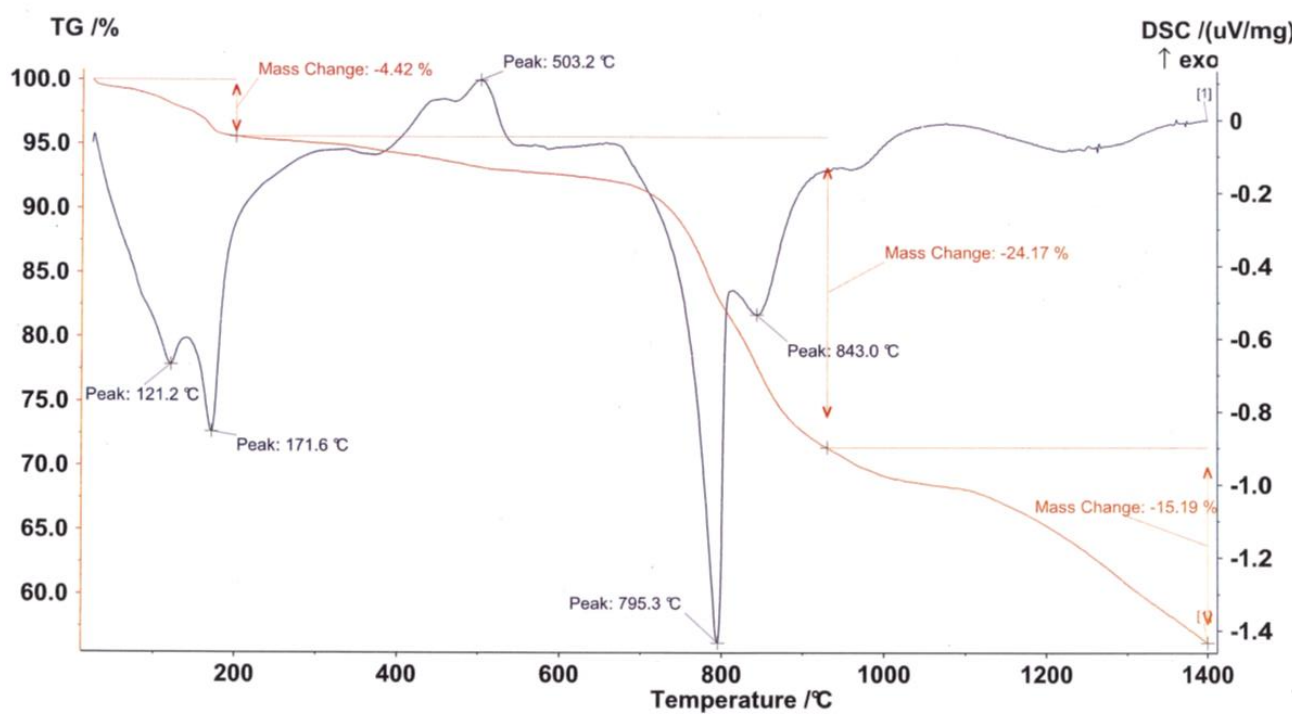

Figure 5. Salamino thermogravimetric analyses 


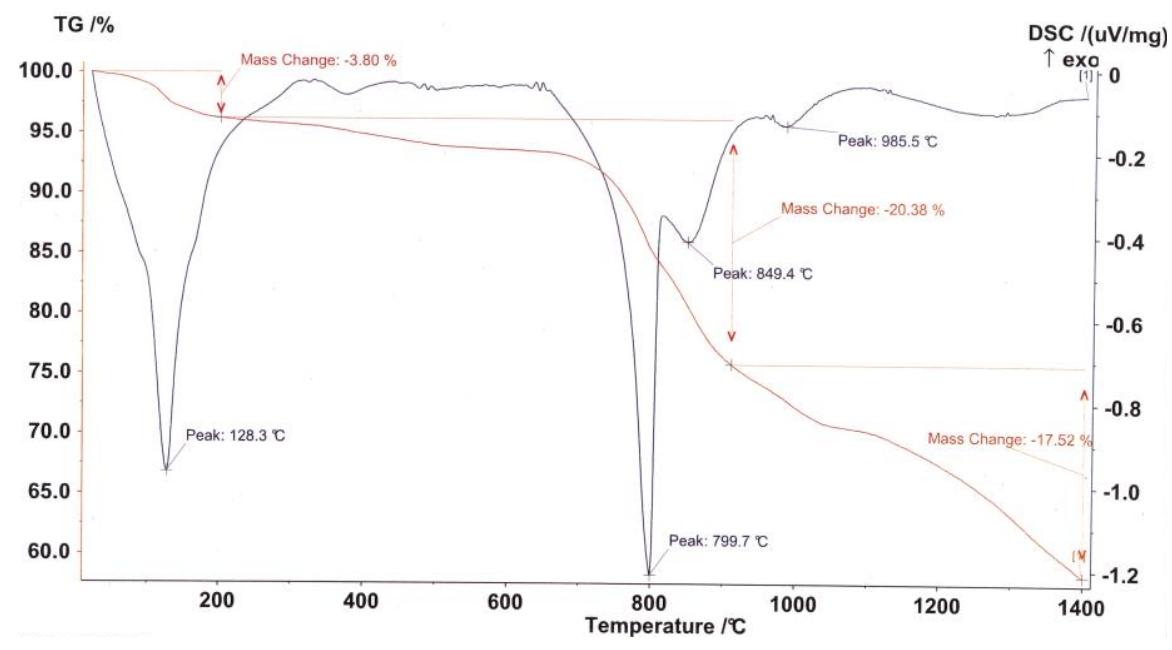

Figure 6. Grasparossa thermogravimetric analyses

Table 4 summarized the four moisture contents of the various kind of vine prunings expressed on wet basis.

Table 4. Biomass moisture

\begin{tabular}{cc}
\hline Biomass & Moisture [\%] \\
\hline Sangiovese & $7.4 \pm 0.4$ \\
\hline Salamino & $6.7 \pm 0.4$ \\
\hline Trebbiano & $8.6 \pm 0.4$ \\
\hline Grasparossa & $7.9 \pm 0.4$ \\
\hline
\end{tabular}

\subsection{Combustion tests results}

Figures 7, 8, 9 and 10 show the temperatures trend of the four combustion tests with the various kind of fuels. It is possible to see that the hot air temperature was quite stable even the combustion chamber one is not. This instability is correlated with the refilling, each arrival of fresh biomass in the stove core was causing the drop of the temperature and probably even the quality of combustion. In Table 5 all the results of the combustion tests with the hot air generator are summarized.

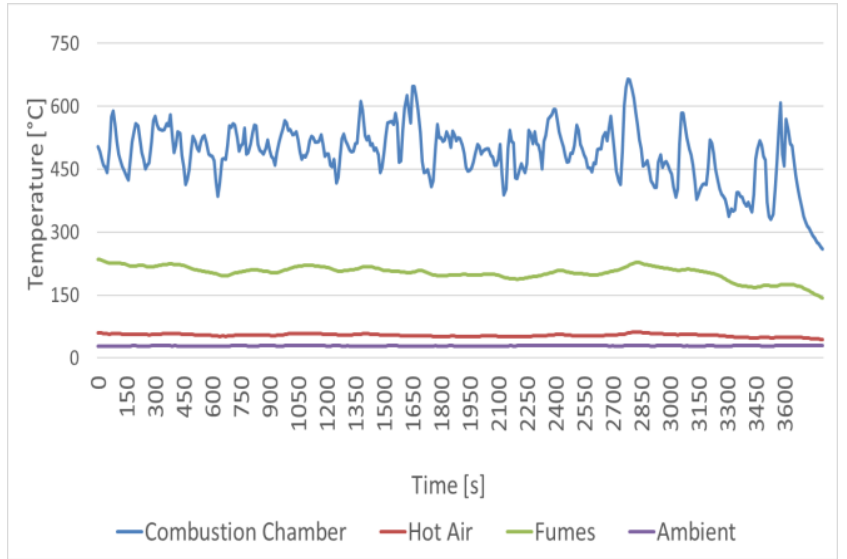

Figure 7. Sangiovese

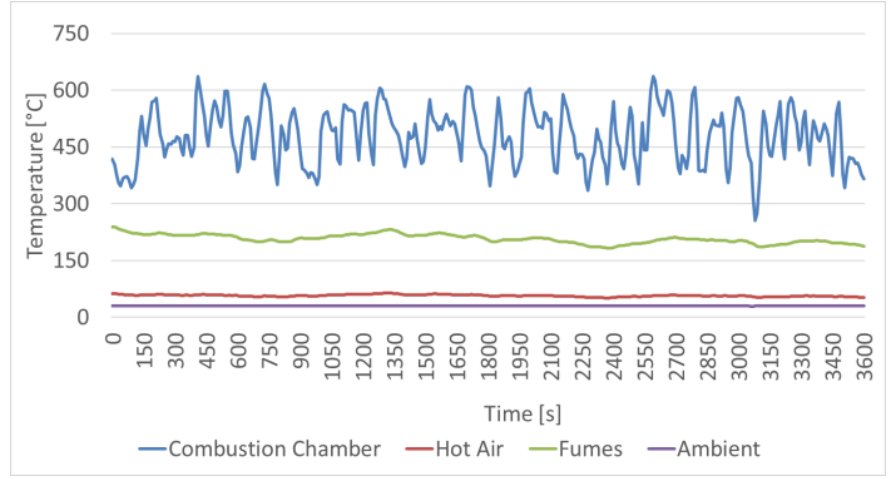

Figure 8. Trebbiano

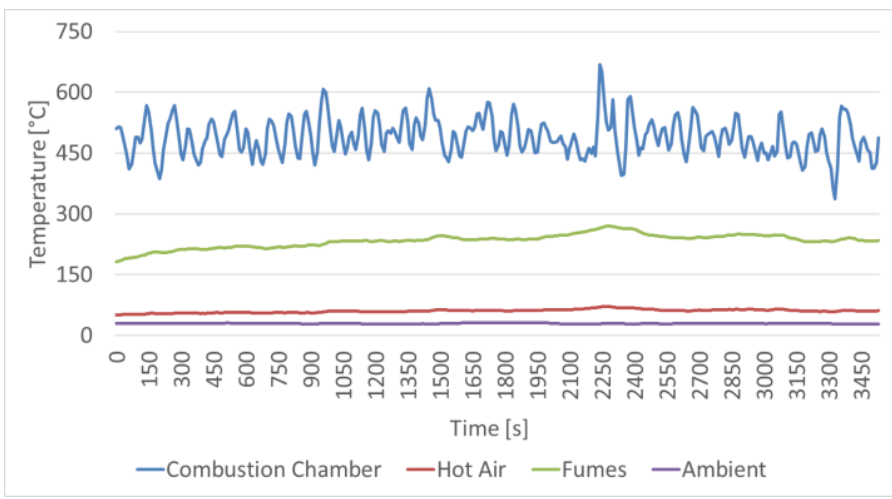

Figure 9. Salamino

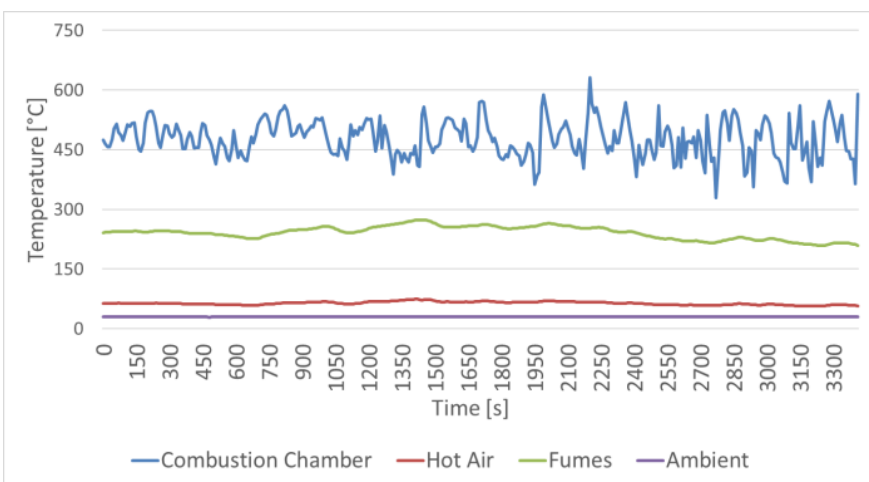

Figure 10. Grasparossa 
Table 5. Combustion test results

\begin{tabular}{|c|c|c|c|c|c|}
\hline Biom & San & Treb & Sal & Gras & Pel \\
\hline $\begin{array}{c}\mathrm{HHV} \\
{[\mathrm{MJ} / \mathrm{kg}]}\end{array}$ & $\begin{array}{l}18.54 \\
\pm 0.02\end{array}$ & $\begin{array}{c}18.25 \\
\pm 0.02\end{array}$ & $\begin{array}{r}18.09 \\
\pm 0.02\end{array}$ & $\begin{array}{c}19.21 \\
\pm 0.02\end{array}$ & $\begin{array}{c}19.0 \pm \\
0.1[10]\end{array}$ \\
\hline $\mathrm{Q}\left[\mathrm{m}^{3} / \mathrm{h}\right]$ & $\begin{array}{c}1,290 \\
\pm 10\end{array}$ & $\begin{array}{l}1,230 \\
\pm 10\end{array}$ & $\begin{array}{l}1,280 \\
\pm 10\end{array}$ & $\begin{array}{l}1,290 \\
\pm 10\end{array}$ & $\begin{array}{l}1,420 \pm \\
10[10]\end{array}$ \\
\hline $\begin{array}{c}\text { Av HAT } \\
{\left[{ }^{\circ} \mathrm{C}\right]}\end{array}$ & $\begin{array}{r}55.0 \\
\pm 0.1\end{array}$ & $\begin{array}{r}57.3 \\
\pm 0.1\end{array}$ & $\begin{array}{r}60.3 \\
\pm 0.1\end{array}$ & $\begin{array}{r}63.9 \\
\pm 0.1\end{array}$ & $\begin{array}{c}58.9 \pm \\
0.1[10]\end{array}$ \\
\hline $\begin{array}{c}\text { Av AT } \\
{\left[{ }^{\circ} \mathrm{C}\right]}\end{array}$ & $\begin{array}{r}29.0 \\
\pm 0.1\end{array}$ & $\begin{array}{r}30.3 \\
\pm 0.1\end{array}$ & $\begin{array}{r}29.5 \\
\pm 0.1\end{array}$ & $\begin{array}{r}29.9 \\
\pm 0.1\end{array}$ & $\begin{array}{c}17.8 \pm \\
0.1[10]\end{array}$ \\
\hline $\begin{array}{l}\mathrm{Av} \Delta \mathrm{T} \\
{\left[{ }^{\circ} \mathrm{C}\right]}\end{array}$ & $\begin{array}{r}26.0 \\
\pm 0.2\end{array}$ & $\begin{array}{r}27.0 \\
\pm 0.2\end{array}$ & $\begin{array}{c}30.8 \\
\pm 0.2\end{array}$ & $\begin{array}{r}34.0 \\
\pm 0.2\end{array}$ & $\begin{array}{c}41.1 \pm \\
0.2[10]\end{array}$ \\
\hline $\mathrm{P}[\mathrm{kW}]$ & $\begin{array}{c}12.1 \\
\pm 0.2\end{array}$ & $\begin{array}{r}12.0 \\
\pm 0.2\end{array}$ & $\begin{array}{r}14.2 \\
\pm 0.2\end{array}$ & $\begin{array}{r}15.9 \\
\pm 0.2\end{array}$ & $\begin{array}{c}15.8 \pm \\
0.2[10]\end{array}$ \\
\hline $\begin{array}{c}\mathrm{M}_{\mathrm{dry}} \\
{[\mathrm{kg} / \mathrm{h}]}\end{array}$ & $\begin{array}{c}4.63 \\
\pm 0.01\end{array}$ & $\begin{array}{c}4.94 \\
\pm 0.01\end{array}$ & $\begin{array}{c}5.41 \\
\pm 0.01\end{array}$ & $\begin{array}{c}5.07 \\
\pm 0.01\end{array}$ & $\begin{array}{c}5.4 \pm \\
0.1[10]\end{array}$ \\
\hline$\eta[\%]$ & $51_{1} \pm$ & $\begin{array}{l}48 \\
\pm 1\end{array}$ & $\begin{array}{r}52 \\
\pm 1\end{array}$ & $\begin{array}{r}59 \\
\pm 1\end{array}$ & $\begin{array}{c}55 \pm 1 \\
{[10]}\end{array}$ \\
\hline
\end{tabular}

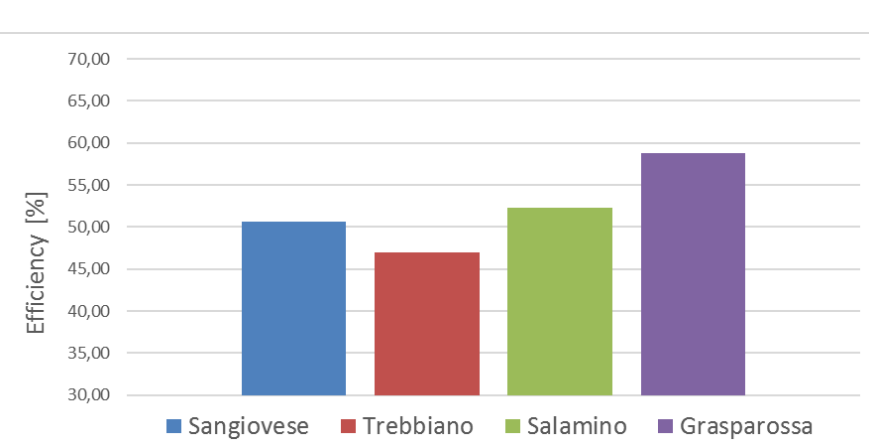

Figure 11. Prunings combustion efficiency

The efficiency of the four tests (Figure 7) was relatively high, especially in the case with the Grasparossa variety, where it was even higher than the one of the test performed with the A1 plus wood pellets.

It is important put in evidence the difference between the ambient temperature during the test with the pellet (around 18 ${ }^{\circ} \mathrm{C}$ ), and the one during the test with vine prunings (around 30 ${ }^{\circ} \mathrm{C}$ ). Probably, if even the combustion test with wood pellet had been performed with an ambient temperature near $30^{\circ} \mathrm{C}$, the efficiency would have been higher.

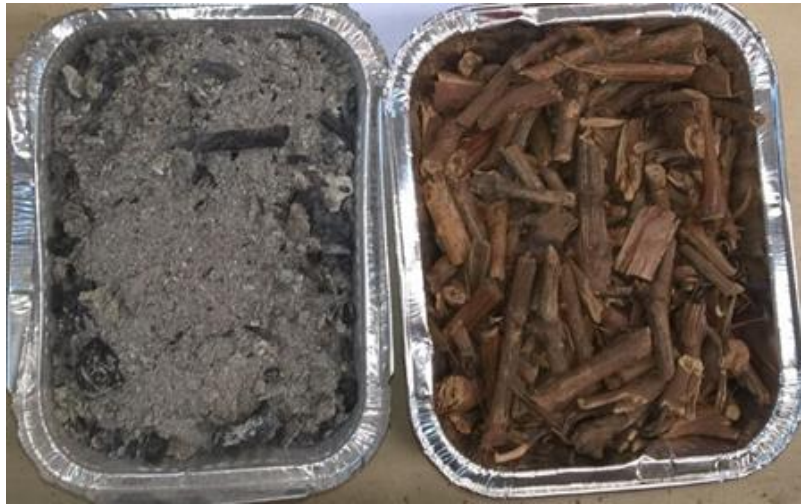

Figure 12. Sangiovese prunings and their ash after the combustion test

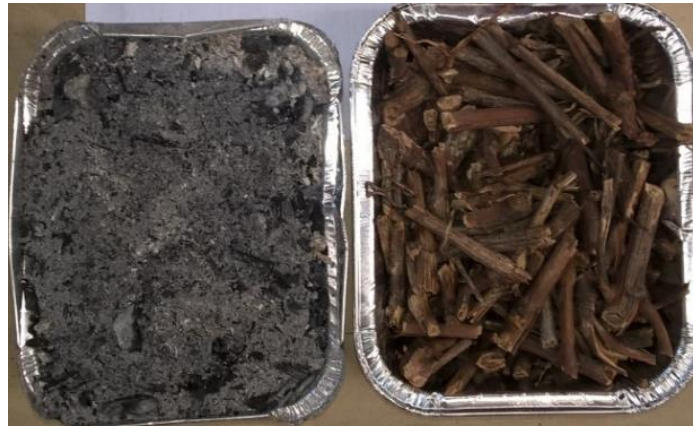

Figure 13. Trebbiano prunings and their ash after the combustion test

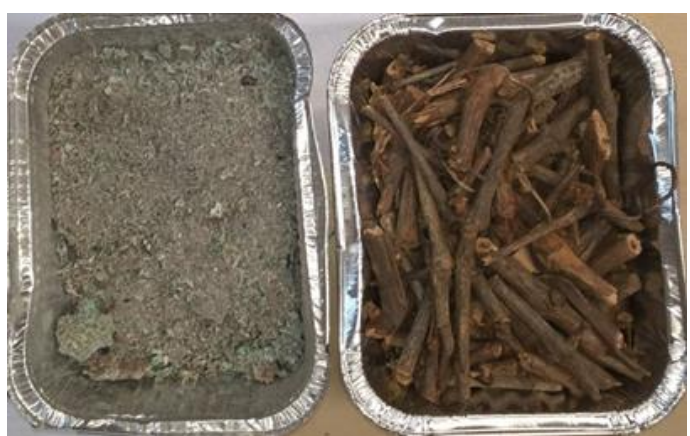

Figure 14. Salamino prunings and their ash after the combustion test

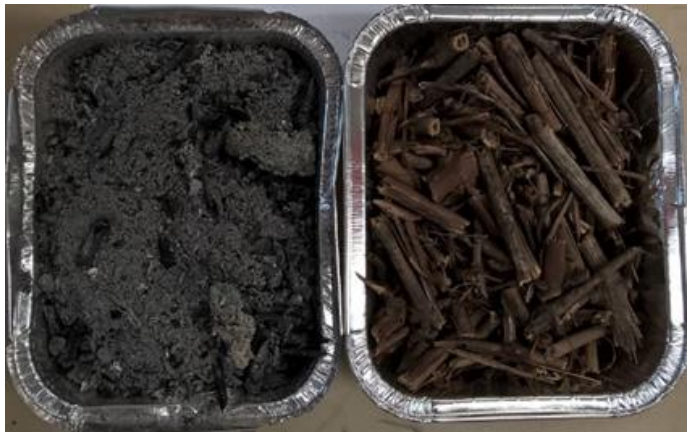

Figure 15. Grasparossa prunings and their ash after the combustion test

Figures 8, 9, 10 and 11 show the look of the prunings both before and after the combustion test. There was no ash sintering problem, in accordance on what was expected due to the high sintering temperature of this kind of biomass that is above $1000{ }^{\circ} \mathrm{C}$ for all the tested kind of prunings.

\section{CONCLUSIONS}

The possibility of exploiting vine prunings as fuel for thermal energy generation was investigate in this work. The biomass was analyzed to assess if its chemical characteristics are suitable for this utilization. After it was ascertained, four combustion tests were carried out. All the prunings varieties performed quite well in terms of both efficiency and agglomerate formation. No ash sintering problems was noticed, which would have compromised the quality of the combustion.

This is also confirmed by the high efficiency reached in the four test, especially for the Grasparossa that reached almost the $59 \%$. This value is higher even than the one obtained with 
A1 plus wood pellet, but it is necessary specify that the ambient temperature of these two tests were different, in particular, the one with pellet was about $12{ }^{\circ} \mathrm{C}$ lower.

These results showed that the vine prunings utilization to generate thermal energy it is not only possible, but can be an interesting alternative to the current disposal of this biomass due to its good properties as fuel.

\subsection{Future works}

Gasification is a chemical process that transform carbonaceous materials into a gasous fuel [11]. Exploiting this gas to run an engine connected to a generator it is possible to produce both thermal and electrical energy from different kind of biomass [11]. Test with this kind of power plants, utilizing vine prunings as fuel, will be performed to assess the feasibility and the efficiency of the process, and compare it to the combustion of these agricultural residues.

\section{ACKNOWLEDGMENT}

The authors would like to thank Francesco Allegretti and Matteo Sassatelli for their help with the combustion tests.

\section{REFERENCES}

[1] Barella P.A. (2010). L'uso energetico dei sarmenti della vite - valutazioni tecnico economiche di filiere significative in provincia di Treviso, Veneto Agricoltura.

[2] Picchi G., Silvestri S., Cristoforetti A. (2013). Vineyard residues as a fuel for domestic boilers in Trento Province (Italy): Comparison to wood chips and means of polluting emissions control, Fuel. DOI: 10.1016/j.fuel.2013.05.058

[3] Filkoski R.V., Petrovski I.J. (2014). Research on the possibility of using agriculture biomass residues for energy purposes, Proceedings of SEEP2014.

[4] Ruiz J.A., Juàrez M.C., Morales M.P., Muñoz P., Mendivil M.A. (2013). Biomass logistics: Financial \& environmental costs, Biomass \& Bioenergy, DOI: $\underline{\text { 10.1016/j.biombioe.2013.05.014 }}$

[5] Ntalos G.A., Athanasios H. (2002). Grigoriou, Characterization and utilisation of vine prunings as a wood substitute for particleboard production, Industrial Crops and Products. DOI: 10.1016/S09266690(02)00008-0

[6] Goncalves C., Evtyugina M., Alves C., Monteiro C., Pio C., Tomé M. (2011). Organic particulate emissions from field burning of garden and agriculture residues, Atmos. Res, Vol. 101, pp. 666-680. DOI: 10.1016/j.atmosres.2011.04.017

[7] Keshtkar H., Ashbaugh L. (2007). Size distribution of polycyclic aromatic hydro-carbon particulate emission factors from agricultural burning, Atmospheric
Environment, Vol. 41, pp.

2729-2739.

DOI: 10.1016/j.atmosenv.2006.11.043

[8] ASTM. (1995). E1755-95 standard test method for ash in biomass, Tech. rep. ASTM International. DOI: 10.1520/E1755-95

[9] Basu P. (2010). Biomass gasification and pyrolysis, practical design and theory, Vol. 2, pp. 54-59. DOI: 10.1016/B978-0-12-374988-8.00001-5

[10] Pedrazzi S., Allesina G., Bellò T., Rinaldini C.A., Tartarini P. (2015). Digestate as bio-fuel in domestic furnaces, Fuel Processing Technology, Vol. 130, pp. 172-178. DOI: 10.1016/i.fuproc.2014.10.006

[11] Basu P. (2010). Biomass gasification and pyrolysis, practical design and theory, Vol. 1, pp. 1-12. DOI: $\underline{10.1016 / \mathrm{B} 978-0-12-374988-8.00001-5}$

\section{NOMENCLATURE}

$\begin{array}{ll}\mathrm{Mo}_{\text {wet }} & \text { Biomass moisture on wet basis, \% } \\ \mathrm{W}_{\text {wet }} & \text { Wet biomass weight, kg } \\ \mathrm{W}_{\text {dry }} & \text { Dry biomass weight, kg } \\ \mathrm{HHV} & \text { Higher heating value, MJ. kg-1 } \\ \mathrm{C} & \text { Carbon fraction } \\ \mathrm{H} & \text { Hydrogen fraction } \\ \mathrm{S} & \text { Sulfur fraction } \\ \mathrm{O} & \text { Oxygen fraction } \\ \mathrm{N} & \text { Nitrogen fraction } \\ \mathrm{HHV} & \text { Higher heating value, MJ. kg-1 } \\ \mathrm{Q} & \text { Hot volumetric air flow, m3. s-1 } \\ \mathrm{Se} & \text { Sectional area of the tubes, m2 } \\ \mathrm{v} & \text { Air velocity, m. s-1 } \\ \mathrm{P} & \text { Thermal power output, kW } \\ \Delta \mathrm{T} & \text { Difference between ambiental and hot air } \\ \mathrm{C}_{\mathrm{p}, \text { air }} & \text { temperatures, K } \\ \mathrm{Av} H A T & \text { Heat capacity at constant pressure, J. K-1 } \\ \text { Av AT } & \text { Average hot air temperature, K } \\ \mathrm{Av} \Delta \mathrm{T} & \text { Average ambient temperature, K } \\ \mathrm{M} & \text { Average difference between ambiental } \\ \mathrm{h} & \text { and hot air temperatures, K } \\ \mathrm{t} & \text { Biomass consumption, kg. s-1 } \\ \mathrm{ha} & \text { hours } \\ & \text { tons } \\ \text { hectares }\end{array}$

\section{Greek symbols}

$\begin{array}{ll}\rho_{\text {air }} & \text { Air density, kg. m-3 } \\ \eta & \text { Hot air generator efficiency }\end{array}$

\section{Subscripts}

San

Treb

Sal

Gras

Pel

\section{Hot air generator efficiency}

Sangiovese prunings
Trebbiano prunings
Salamino prunings
Grasparossa prunings
A1 plus wood pellets

